DOI: 10.17234/SRAZ.64.5

UDC: 821.111.09 Dickens, C.

\title{
Circulation of Capital in Great Expectations
}

\author{
Borislav Knežević \\ Faculty of Humanities and Social Sciences \\ University of Zagreb \\ bknezevi@ffzg.hr
}

\begin{abstract}
The article discusses the theme of acquisition and circulation of capital in Charles Dickens's novel Great Expectations. The analysis proceeds from an observation that the novel is not centrally concerned with representing the processes of production of wealth, as it is about the circulation of social and economic capital. The protagonist of the novel entertains a specific notion of social mobility (his great expectations), which he eventually renounces, and develops a common middle-class idea of the centrality of hard work to the accumulation of wealth. However, by examining the construction of the protagonist's relationship to wealth, as well as the construction of the circulation of wealth in the narrative, the article suggests that the novel questions its declarative ideology by placing a great deal of emphasis on the various ways in which transfers of money enable the creation of social and economic capital for the characters in the novel.
\end{abstract}

Key words: Charles Dickens, middle class, capital, work, British Empire

In Great Expectations (1860-61) a number of characters entertain expectations as forms of social ambition. Pip wants to become "a gentleman on [Estella's] account" (133). Magwitch wants Pip to become a gentleman, and to be "above work" (297). Herbert Pocket, or as Pip first dubs him, "a pale young gentleman" (99), teaches Pip gentlemanly manners, while having expectations of wealth to amend his relative poverty. Miss Havisham's father, "a country gentleman" (175) and owner of a brewery, was, in Herbert's words, "very rich and very proud" (176); that is, he was not only wealthy but also arrogant about his class status. Uncle Pumblechook expects the result of the young Pip's acquaintance with Miss Havisham to be Pip's getting apprenticed to "some genteel trade" (81), like his own, emphasis of course being on genteel rather than trade. It is only Joe Gargery and Biddy who stay away from this kind of ideological discourse and its preoccupation with social status. On one level, the different expectations of wealth and status are featured in the novel as misjudgements associated with individual dispositions; so for instance, Herbert entertains fantasies of magnificent 
capitalist success, which is coupled with his business artlessness, at least initially. Pip is established early on in the narrative as a master of misreading, and later he pursues his expectations of a gentlemanly life based on the misinterpretation that Miss Havisham is his benefactor. But more than just being presented as personal delusions, the great expectations of social mobility are dramatized in the novel as forms of a social malaise afflicting the middle class, and helping shape the cultures and economies of that social group, which was the primary addressee of Charles Dickens's novelistic imagination.

Pip's early misreadings about his parents and siblings (which he makes on the basis of the shape of the inscriptions on their tombstones) at the beginning of the narrative are attributable to the context of his bringing up: he is a child whose older sister probably did not care to share with him any information on their family. However, it should be noted that the very theme of misreading is foregrounded by the narrative format, that of autobiography, which relies on enacting, throughout the text, differences between the experiencing Pip and the narrating Pip, with the narrator possessing the wisdom unavailable to the protagonist, made possible by a process of arriving at a reformed understanding of both self and the world. Pip's long-lasting state of delusive great expectations is not constructed in the narrative as being continuously simple and complete; interestingly, the text occasionally projects in his misapprehensions a discrepancy between knowing and acting, or a discrepancy between adhering to two incongruous positions at once. In the story Pip's delusion is sometimes accompanied by instances of comprehension. In addition to this double consciousness of the experiencing Pip, there are the complications presented by the narrative format, inasmuch as the voice of the narrating Pip, acquired after the recognition of his delusion, necessarily casts its authority and idiom over the (interpretation of the) experiences of the narrated Pip. The text thus requires that its reading be attentive to differences and overlaps between the narrator's and protagonist's views, as well as to the narrator's understanding of the protagonist's misunderstandings, which are featured in different gradations of pretence and self-deception. ${ }^{1}$

1 In Reading for the Plot Peter Brooks remarked that " $t$ ] he question of texts, reading, and interpretation is [...] consistently thematized in the novel" (1984: 131). His analysis, framed by psychoanalytic discourse, focuses on the novel as an exemplary text about plot (Great Expectations is a text which "gives in the highest degree the impression that its central meanings depend on the workings-out of its plot" 1984: 114). In the scene of Magwitch's return Pip realizes who his benefactor is, and this is a turning point in the narrative: "All the truth of my position came flashing on me; and its disappointments, dangers, disgraces, consequences of all kinds rushed in [...]" (Dickens 1996: 297). Brooks sees this as a central episode in the structuring of the plot; "[t]he return of the repressed - the repressed as knowledge of the self's other story, the true history of its misapprehended desire-forces a total revision of the subject's relation to the orders within which it constitutes meaning" (1984: 129). While Brooks's approach to this revision is to examine the plot in a formalist/psychoanalytical manner, my perspective on the significance of this moment in the plot (Pip's realization of his misapprehension of his own circumstances and of its consequences) is that it is a very specific ideological 
While various characters in the novel embody narratives about different versions of social aspirations, the massive appeal of the pursuit of such aspirations also informs the way in which the novel represents the domains of economy and work. It is a particularly distinctive feature of the imaginative work of this novel that economic issues are shown to permeate and shape the lives of its characters, yet the economic realm is associated with disposition rather than production of wealth, just as the novel is less concerned with dramatizing the social causes of poverty than it is with the individual attempts to escape it. This essay will attempt to chart and examine some of the ways in which the circulation of capital is represented in the novel-both capital in economic terms as money, and capital in social terms as social status. ${ }^{2}$ Much of the narrative focus of Great Expectations is about the transformation of one form of capital into another: Magwitch attempts to use his economic capital to furnish Pip with the social capital of a gentleman, while eventually Pip is able to convert his gentlemanly social capital into a career in which he can make money.

It should be remembered that the imaginative scopes of Dickens's novels are not comprehensively representative of national life, either geographically or socially: most of his novels primarily focus on middle-class life in London. ${ }^{3}$ Dickens's novels exude a disapproval of the continuing patrician dominance of government (as is the case in Little Dorrit), and they commonly register a pervasive impact of hierarchy across society, but there is no extensive focus in his novelistic oeuvre on the social world of the landed classes. His narratives are populated with a large gallery of characters, many of them belonging to the urban poor, with the protagonists usually being or becoming middle-class. But more than just representing a specific class sensibility and class perspective, Dickens's narratives are often built around expressing an anxiety about the

turning point: it marks the demise of Pip's previously entertained fantasy of gentility and the beginning of the making of his new identity, one which is eventually based on the very different ideological assumption of hard work. The question of Pip's self-construction in the narrative thus needs to be posed also as the question of the persuasiveness of the new set of values he develops after that episode.

2 In the sociology of Pierre Bourdieu one of the central analytical instruments is a differentiation between different forms of capital (such as economic, cultural, social and symbolic). In an essay on social class Bourdieu wrote that social capital "consists of resources based on connections and group membership," while symbolic capital "is the form the different types of capital take once they are perceived and recognized as legitimate" (1987: 4). Social capital is predicated on belonging to a group; symbolic capital is associated with the way a social position is perceived. In this essay I will use the term social capital to cover both symbolic capital and social capital in Bourdieu's understanding. Pip's helping Herbert get a job at Clarriker's, and later getting a job with the same company, can be seen as a simple example of forming group connections. An example of the role of social prestige (or more strictly, symbolic capital in Bourdieu's sense of the term) in the novel is Pip's ability to contract considerable debts based on his perceived gentlemanly status.

3 Of course, there is Hard Times, which is not set in London but in a fictional industrial city of Coketown. 
fragility of middle-class ethos, assailed as he finds it by various temptations concerning acquisition and use of wealth, such as the temptation of acquisition of wealth without work that originates in specific capitalist practices and the temptation of genteel aspirations that originates in the adaptable and resilient system of class hierarchy.

Overall, in spite of often elaborate references to specific trades and businesses, Dickens's novels usually do not directly represent the actual operations of, and the actual work involved in, the economic processes which frame the narratives. In Great Expectations this distance is assumed over and over again: for instance, Pip learns very late, and only incompletely, how the money was made that his mysterious benefactor lavished on him; Herbert Pocket has no clue how he lands the job that makes his career (until much later); the text furnishes only scant information on the particulars of the work that Pip actually does at the end of the novel, when he finally does work for a living. Work is very important in this narrative, but what seems to be more important is getting there, that is, getting to the realization that it is so. "I work pretty hard for a sufficient living" (439) - these are Pip's words near the end of the novel, expressing both a change in his attitude to work and acquisition of wealth, and a new sense of what constitutes the acceptable amount of economic ambition in middle-class society. However, in Great Expectations there is not only the issue of unrepresented work; there is also a narrative drift, which is much more substantial in the novel than just an occasional hint, that an ideology of hard work is not persuasive enough, either as an explanation of middle-class wealth or a doctrine about how to acquire it, and that transfer of wealth through patronage and inheritance is not altogether immaterial to middle-class life.

\section{Wretched hankerings after money and gentility}

By the end of the narrative Pip is able to draw moral and ideological lessons from his experiences; since the narrative is presented in the first person the reader is continuously faced with the task of discerning and interpreting the differences between the experiencing Pip and the narrating (reformed) Pip. Firstperson narration necessarily complicates the seemingly simple melodramatic plot trajectory from Pip's delusion (his great expectations) to recognition of the delusion (and subsequent reform of his social habitus), ${ }^{4}$ and a careful reading is required to examine the differences (and continuities) between the two Pips.

4 Great Expectations can be regarded as a Bildungsroman with strong melodramatic elements; here I use the term melodramatic broadly along the lines of Peter Brooks's discussion in The Melodramatic Imagination, insofar as the term implies a narrative mode that often utilizes sensationalist constructions of the plot as it strives to present a sense of moral order. For Brooks melodrama is "not a constant among literary modes [...] but a peculiarly modern form" (1976: 14); it is a mode with a specific historical meaning as well as a specific narrative kinship to psychoanalysis. My use of the term here will be focused on the plot: I regard as melodramatic the sensationalist plot that begins with Pip's fascination with dominant discourses on wealth and status and eventually leads to his adoption of an ideologically reformed evaluation of these discourses. 
Consider for example Pip's thoughts on Estella during a visit to Miss Havisham's (at this point he lives in London pursuing the lifestyle of a gentleman):

We sat in the dreamy room among the old strange influences which had so wrought upon me, and I learnt that she had but just come home from France, and that she was going to London. Proud and wilful as of old, she had brought those qualities into such subjection to her beauty that it was impossible and out of nature-or I thought so-to separate them from her beauty. Truly it was impossible to dissociate her presence from all those wretched hankerings after money and gentility that had disturbed my boyhood,-from all those ill-regulated aspirations that had first made me ashamed of home and Joe, - from all those visions that had raised her face in the glowing fire, struck it out of the iron on the anvil, extracted it from the darkness of night to look in at the wooden window of the forge, and flit away. In a word, it was impossible for me to separate her, in the past or in the present, from the innermost life of my life. (225)

At this juncture in his narrative Pip reflects on his relationship with Estella: what does actually motivate his romantic fascination with her? In a moment of remarkable self-analysis, the experiencing Pip attributes his enchantment with Estella to "all those wretched hankerings after money and gentility that had disturbed my boyhood." The mention in the quoted passage of "all those ill-regulated aspirations that had first made me ashamed of home and Joe," has an arguably Bildungsroman effect, inasmuch as it seems to underscore the motif of the education of Pip's mind (or at least an eventual falling away of his "ill-regulated aspirations"). Thus, one drift of the narrative work is to produce a reformed Pip, one who has overcome the errors of his early ways and developed a new kind of social habitus, presumably exemplifying the contemporary middleclass tenets of self-making and hard work. However, it should be pointed out that in this episode, which takes place at Miss Havisham's, Pip thinks of his fascination with Estella (and her association with the notion of gentility) as "the innermost life of my life," which is what he feels at the time of the episode, and also for a much longer period. Whether the narrative eventually finds a way to reconstruct their relationship on a different basis is somewhat inconclusive. If Pip is to remake his relationship to wealth and status through hard work, he also needs to reshape his ideas about romantic love away from "those wretched hankerings after money and gentility," and at the end of the story we cannot be entirely sure how these things are to be reimagined.

Already before his first visit to Miss Havisham's, Pip is introduced to a version of snobbish concern with class in his own family (modest as its situation is), as is evidenced by his description of what was planned for him from an early age:

When I was old enough, I was to be apprenticed to Joe, and until I could assume that dignity I was not to be what Mrs. Joe called "Pompeyed," or (as I render it) pampered. Therefore, I was not only odd-boy about the forge, but if any neighbour happened to want an extra boy to frighten birds, or pick up stones, or do any such job, I was favoured with the employment. In order, however, that our superior position might not be compromised thereby, a 
money-box was kept on the kitchen mantel-shelf, into which it was publicly made known that all my earnings were dropped. I have an impression that they were to be contributed eventually towards the liquidation of the National Debt, but I know I had no hope of any personal participation in the treasure. (58-59) ${ }^{5}$

Mrs. Joe is one of a large gallery of Dickens's characters whose social aspirations are informed by an internalization of the discourse of hierarchy; being an apprentice is a "dignity," and the Gargerys presumably enjoy a "superior position" in their neighbourhood. Interestingly enough, Pip is not only meant to be trained in a life of avoiding idleness (therefore the odd jobs even before he is to be apprenticed, which reveals a touch of common middle-class emphasis on the importance of work on the part of Mrs. Joe), but he is also taught that his working for money should not compromise the family's standing in the neighbourhood, by which the narrative foregrounds that the ideology of gentility (informed by adherence to a hierarchical class system and a preference for possession of wealth without a visible effort of working for it) resonates also among the lower strata of the social hierarchy. The same kind of perspective on the structure of British society comes through in Magwitch's words to Pip on his life in Australia: "I worked hard, that you should be above work" (297). Work is good-up to a point, but it is better to enjoy high social status without the nuisance of having to toil. Once again, the middle-class ethos that drives the narrative involves a conclusion that hard work is more important than status, or, at the very least, that status is important only insofar as it proceeds from hard work. But the narrative also suggests that its characters inhabit a social world in which this tension between the creation of wealth through one's own effort and the appeal of the prestige of genteel status (unencumbered by a visible relationship to work) is not effectively resolved.

While Pip's conditioning by the genteel ideology begins very early on, the narrative also suggests that the young Pip is not wholly or irremediably shaped by his sister's or Pumblechook's aspirations. Recounting his second visit to Miss Havisham's Pip remarks:

There were three ladies in the room and one gentleman. Before I had been standing at the window five minutes, they somehow conveyed to me that they were all toadies and humbugs, but that each of them pretended not to know that the others were toadies and humbugs: because the admission that he or she did know it, would have made him or her out to be a toady and humbug. (91)

The language of the description is focused, with surprising poignancy for the young Pip, on the mechanism of sycophancy and pretence (the three ladies and one gentleman are Miss Havisham's relatives; as it turns out later they are waiting to be received by her on her birthday, and will take the opportunity to try to ingratiate themselves with her). What Pip realizes is not only that each of the company assembled is a toady, but also that all of them know that of the others

5 The reference to the national debt is a retrospective comment on the situation by the narrating Pip (as the present tense suggests: "I have an impression [...]"); the passage suggests that he did not benefit from the money he earned. 
and uphold the mutual pretences. That Pip "somehow" is able to see through this in less than five minutes of being there, and form a judgment on the people in the room, is an indication that his early conditioning along the lines of status aspirations does not prevent him from recognizing toadies. Let us remember that in general the plot is organized around Pip's particularly persistent habit of misreading things and forming misguided expectations, but in this instance the experiencing Pip provides an analytical frame that is quite close to that of the narrating Pip. This could in turn be regarded as the novel's insistence on the complexity of Pip's character; in spite of his inclination to misreading, the experiencing Pip is also established as an occasional focal point of the novel's social analysis. Of course, the episode also serves to underscore the irony of the fact that Pip too comes to expect to benefit from Miss Havisham.

Early in the narrative, there is an interesting instance of Pip's fascination with wealth and status which puts this fascination in the context of broader social orders and economies. Having acquired some very basic knowledge at Mr. Wopsle's great-aunt's evening school (but mostly from Biddy), Pip tries to convey some of it to Joe (so as to make him "less ignorant and common, that he might be worthier of my society and less open to Estella's reproach"). He helps Joe study on the marshes, and the narrating Pip remembers the surrounding scene:

It was pleasant and quiet, out there with the sails on the river passing beyond the earthwork, and sometimes, when the tide was low, looking as if they belonged to sunken ships that were still sailing on at the bottom of the water. Whenever I watched the vessels standing out to sea with their white sails spread, I somehow thought of Miss Havisham and Estella; and whenever the light struck aslant, afar off, upon a cloud or sail or green hillside or water-line, it was just the same. - Miss Havisham and Estella and the strange house and the strange life appeared to have something to do with everything that was picturesque. (116)

In a study of the significance of the theme of global transport in the novel Jonathan H. Grossman comments on the location of Pip's early life: “On one side, an international oceanic highway - the Thames - runs right past Pip's home. On the other side speeds one of the busiest and oldest roads in England, the Dover road, also a gateway to the continent" (2015: 229). Pip does not dwell much on these geographic facts at this point in his narration, but the narrative does in its own way: the sails that fascinate Pip are metonymies of a global system of power and trade, the British domination of the seas and maritime commerce, and the growing extension of the empire. ${ }^{6}$ In the passage, the phrase "everything that was picturesque" refers to the scenery that captures Pip's imagination at this point

6 At the beginning of the story Magwitch has just escaped from the hulk (a floating prison-ship), where he was held awaiting transportation to New South Wales, a far-flung part of the British Empire. Interestingly, in the picturesque scenery that Pip admires in the quoted passage there seems to be no reference to the earlier episode involving the hulk, suggesting that Pip's watching the ships on the river conveys a fascination with an idealized image of British maritime power. 
(such as the way light falls on the natural features of the landscape - the hillside or the waterline). However, the image given a central place in the passage is that of the ships "standing out to sea with their white sails spread," an evocation of a society on the move, and an indication of an iconic appeal that the ships have for Pip. The image of the ships is also related here to the notion of social mobility that has come to increasingly preoccupy him as he is already convinced that he "should never like Joe's trade" (113). Pip states that his delight in the picturesqueness of the landscape and the ships about to set out bears the imprint of his fascination with Miss Havisham and Estella and the life they stand for; the ships, and the landscape that frames the scene, are interesting to him for being "picturesque," but they also make him think of the world of Miss Havisham and Estella. His desire for upward mobility, which is linked to his visits to Satis House, is thus shown to be projected into his fascination with the scenery featuring the ships (and the imperial and commercial British power that they represent). There is a suggestion here of the significance of an imaginary quality to Pip's fascination with the ships (the sails looking from his vantage point "when the tide was low, $[\ldots]$ as if they belonged to sunken ships that were still sailing on at the bottom of the water"); just as Pip sometimes cannot get a good look at the ships on the river (so that the sails actually look as the synecdoches of the ships), so his young mind does not show much of an understanding of the realities or the specifics of the global network of shipping routes, commerce and politics that the ships circumscribe. But even as he is not concerned with grasping the whole picture, his ambitions are framed by it. The young Pip, however poor and poorly educated, is shaped by the facts of the British Empire and British commercial power, as well as by a perception of social prestige that he associates with Miss Havisham and Estella. As Pip tries to act as Joe's tutor to make him more respectable, his own desires and views have already been scripted by social forces beyond his ability to fully understand. Immediately before this episode, Pip comments on his having become "ashamed of home" (113): "How much of my ungracious condition of mind was my own fault, how much Miss Havisham's, how much my sister's, is now of no moment to me or any one. The change was made in me; the thing was done" (114). The narrator's point is simple: Pip's habituation to the genteel ideology may have been facilitated by different factors, but from the perspective of the unfolding of his story what matters is that it has come to intensely shape his views. Years later, after the conversation in which Magwitch reveals himself as his benefactor, Pip writes: "For an hour or more, I remained too stunned to think; and it was not until I began to think, that I began fully to know how wrecked I was, and how the ship in which I had sailed had gone to pieces" (301). ${ }^{7}$

7 Grossman suggests that Pip's words here are inspired by Magwitch's words earlier in their conversation, that Australia is "many a thousand mile of stormy water off from this" (Dickens 296), which evoke his sea journey (Grossman 2015: 234). Yet, at this juncture in his narrative Pip proceeds to speak of the shattering of his great expectations 


\section{Sixpennorth of halfpence}

At the beginning of the novel Pip is an orphan with limited prospects of material wealth. As Pumblechook the corn-chandler makes his appearance in the Christmas dinner scene, he refers to Pip as "Sixpennorth of halfpence" (42). Pumblechook uses the phrase as Pip's name and a condescending representation of a small amount of money; it is an indication of his tendency to measure everything and everyone primarily in terms of monetary value. Pumblechook's words could be taken to express a low estimation of Pip's situation in life and possibly his prospects (as well as Pumblechook's sense of class superiority).

But while Pip enters the story in relative poverty, his encounter with Magwitch the convict at the very beginning of the novel highlights a different type of social disadvantage. Pip is an orphan who lives with his relatives and has the prospects of joining the artisanate (as Joe's apprentice); Magwitch's destitution was much more radical, for he was an orphan with no family connections left, and much of his life was spent in crime. Magwitch conveys a sketchy outline of his experience of poverty, as he tells Pip the story of his life in England ("[i]n jail and out of jail"). Even his earliest memories involve deprivation and crime: "I first become aware of myself down in Essex, a thieving turnips for my living." He spends much of his youth in vagrancy, "tramping, begging, thieving, working sometimes when I could" (319). Most of his account of his life in England has to do with his association with Compeyson, who had "been to a public boarding-school and had learning. He was a smooth one to talk, and was a dab at the ways of the gentlefolks" (320). Compeyson drags him into a life of a different kind of crime: "Compeyson's business was the swindling, handwriting forging, stolen banknote passing, and such-like" (321). The narrative emphasizes the importance of social hierarchy and status to the different fortunes of Magwitch and Compeyson in their criminal careers. Magwitch's association with Compeyson, with whom he has a double relationship as servant and "pardner" (321), is a relationship of subordination rather than partnership: "I was always in debt to him, always under his thumb, always a working, always a getting into danger" (322). In their trial "on a charge of putting stolen notes in circulation - and there was other charges behind" (323), Magwitch received a heavier sentence than Compeyson, whose counsellor presented him as being superior to Magwitch in class terms to some effect. ${ }^{8}$ Later, as a convict and then an ex-convict in Australia, a far-off extension of the British social world, Magwitch could not aspire to be seen as a gentleman regardless of his ability to acquire substantial wealth there over time.

("Miss Havisham's intentions towards me, all a mere dream; Estella not designed for me" 301); thus his using at this point the metaphor of the ship (and his being wrecked) is a reference to his early delight in the picturesque scenery involving ships as well as his fascination with the social status of Miss Havisham and Estella.

8 After his escape from the prison-ship Magwitch realizes Compeyson escaped too, and he tries to take him back to the prison-ship, when they are both captured. Magwitch is tried again and sentenced to transportation for life, while, as Magwitch tells Pip, Compeyson's "punishment was light" (325). 
Pip's elevation in social status, facilitated by the money Magwitch accumulated in Australia, is an extraordinary level of elevation in comparison to his initial circumstances; Pip's situation at the end of the novel, when he enjoys a "sufficient" level of economic capital, still represents a remarkable story of social mobility. The novel's perspective on the question of what should constitute the desirable form of middle-class affluence appears to be framed by the sentiments eventually embodied in the protagonist (who renounces excessive expectations for hard work and "a sufficient living"). But while Pip eventually follows in the footsteps of Herbert Pocket who comes to exemplify middle-class industry, yet in different ways they both substantially benefit from transfers of economic capital. The novel presents an interesting point of comparison in Wemmick's story, which is also structured by the motif of acquisition: Wemmick's rather different set of possibilities, goals and methods of accumulation underscores the fact that the foundation of Pip's fortunes is in transferred wealth. While Pip in much of the narrative expects to improve his station greatly by his great expectations, Wemmick's preoccupation with what he calls "portable property" is very different in scale. He first uses the term in relation to his jewellery as "gifts" and "curiosities" (194-95) that he has obtained from Jaggers's clients; he tells Pip: "They may not be worth much, but, after all, they're property, and they are portable. It don't signify to you with your brilliant lookout, but as to myself, my guiding-star always is, 'Get hold of portable property"' (195). Wemmick points out the difference in the level of wealth as well as in the importance of the very need for acquisition that separates himself and Pip (because of the gift of his "brilliant lookout," Pip does not need to concern himself with accumulation as much as Wemmick does). Not unlike Herbert Pocket's early discourse on the accumulation of capital, Wemmick is vocal about the principle of economic self-interest; also, not unlike Herbert in his early career, he is not well off. Both exemplify the ideological appeal of economic accumulation, but their stories illustrate different levels of access to it. However, it should be noted that Wemmick uses the term "portable property" in a more general sense as well, to describe not only different kinds of material objects, but also money (for instance, he uses the term in reference to Pip's plan to invest in Herbert's career, or to Magwitch's wealth).

A particular focus of Wemmick's material ambition has been his small area of land with a small house on it which he calls the Castle: "Wemmick told me [...] that it had taken him a good many years to bring the property up to its present pitch of perfection;" when Pip asks him whether the property is his own, Wemmick responds: "O yes [...] I have got hold of it, a bit at a time. It's a freehold" (201). ${ }^{9}$ His miniature castle can be regarded as a literalization of the saying that "a Englishman's ouse is his Castle" (424; this version of the saying is uttered by Joe). While it does not have great economic and social value, Wemmick's "freehold" seems to bear a distant affinity to the socially dominant ideology of gentility -

9 Wemmick's ability to acquire a freehold also foregrounds the fact that Pip, throughout his story as aspiring gentleman, remains without a root in the possession of real property. 
and its origin in ownership of land; it is likewise a small-scale rendition of the agricultural resources of a country estate (behind the house Wemmick keeps a pig, fowls and rabbits, and he grows vegetables in the garden). The construction of the Castle is an example of Wemmick's ability to improve his circumstances on the limited financial means of a clerk, using a range of his own skills. ${ }^{10}$ In addition, the effort that has gone into the making of Wemmick's Castle stands as a counterpoint to the disrepair and bleakness of Miss Havisham's property, Satis House. Wemmick's freehold, in spite of its peculiar design, exemplifies a modestly improving (lower) middle-class life, ${ }^{11}$ in contrast to the arrested world of the much wealthier Miss Havisham.

Her father was, in Herbert's words, "a country gentleman,"12 and the owner of a brewery. Once probably at least a part of the economic basis of the Havishams' wealth, the brewery closed down long before the main story of the novel; on his first visit to Miss Havisham's, Pip notices that in the brewery "all was empty and disused," and Estella tells him that the brewing is now "all done with, and the place will stand as idle as it is till it falls" (69). The collapse of the brewery into idleness is caused by Miss Havisham's reaction to Compeyson's breaking off their relationship just before their wedding was supposed to take place; after that she is no longer associated with capitalist production. Compeyson's deception had the goal of cheating her out of some of her money: "he got great sums of money from her, and he induced her to buy her brother out of a share in the brewery (which had been weakly left him by his father) at an immense price" (177), as Pip is told by Herbert (who reconstructed the story by himself). After Compeyson's deception Miss Havisham stopped all the clocks around the estate at the time when she received the letter from him ending their relationship, including the clock on the outer wall of a house on the site, which Pip says looked "as if it had once belonged

10 Wemmick tells Pip: “I am my own engineer, and my own carpenter, and my own plumber, and my own gardener, and my own Jack of All Trades" (200).

11 It is important to stress that the novel paints a humorous picture of the peculiarities of Wemmick's tiny castle, but it does not define him by excessive expectations of social mobility. Arlene Young discussed Wemmick as an embodiment of "[t]he defining features of the lower middle class," and pointed out that his castle "does not represent self-aggrandizement, but is instead a celebration of the domestic merits of hearth and home" (1996: 496). Young's article raises interesting questions about differences in Dickens's attitudes to the lower middle class and the wealthier segments of the middle class.

12 The narrative offers little information on Mr. Havisham's social background; from Herbert's account the following is known: "Her father was a country gentleman down in your part of the world, and was a brewer. I don't know why it should be a crack thing to be a brewer; but it is indisputable that while you cannot possibly be genteel and bake, you may be as genteel as never was and brew. You see it every day" (175). This raises the question of whether Mr. Havisham's gentlemanly status preceded his brewing business, or whether he based his gentlemanly status on the proceeds from the business. The former may be implied by the fact that Herbert first mentions that Mr. Havisham was a "country gentleman," before saying that he was a brewer. 
to the manager or head clerk of the extinct brewery" 90). There is no evidence in the narrative that keeping the brewery running wouldn't have been possible for lack of money; when Miss Havisham's name first comes up in the story, Pip remembers that she is known "for miles round [...] as an immensely rich and grim lady [...] who led a life of seclusion" (66). The cessation of accumulation of capital through production may suggest Miss Havisham's withdrawal from a concern with further accumulation of money, just as her social isolation seems to mark an indifference to a concern with further advancement of status; at the same time, her detachment from such concerns could also be seen as an eccentric version of haughtiness about inherited status. (It should be noted though that Miss Havisham does not simply live off her father's accumulation, but also makes some money by collecting rent - Pumblechook is her tenant.) There is a strongly sensationalist, melodramatic background to Compeyson's deception: he "acted throughout in concert with her half-brother," with whom he "shared the profits" 178). (Mr. Havisham had cut his son off for his extravagant behaviour but later left him a smaller share of his wealth, which he also wasted.) Herbert describes Mr. Havisham as having been "very rich and very proud," the latter adjective meaning very sensitive about his social status; he also mentions a little later that Mr. Havisham "privately married again - his cook." When Pip expresses surprise over that ("I thought he was proud"), Herbert replies: "[...] so he was. He married his second wife privately, because he was proud" (176). The half-brother was the result of this relationship. Incidentally, in this conversation Herbert is also casually instructing Pip in table manners, a humorous backdrop to his account of the Havishams which unfolds as a sensationalist story of money, status, inheritance and deception - the satirical element to this account is underscored by the fact that Pip's fascination with gentility is greatly shaped by his acquaintance with Miss Havisham and Estella. Herbert's perhaps understated, perhaps guileless account of the Havishams' family history and the varied fortunes of its economic and social capital is delivered, albeit sketchily, in the form of a narrative of sensationalism and satire.

\section{Looking about}

The novel's emphasis on property and expectations of wealth is coupled with a distinct sense that the production of economic wealth in the represented world has somehow taken a stagnant form. Let us consider for instance the following passage in which Pip describes the High-street in the market town in the morning:

[...] Mr. Pumblechook appeared to conduct his business by looking across the street at the saddler, who appeared to transact his business by keeping his eye on the coachmaker, who appeared to get on in life by putting his hands in his pockets and contemplating the baker, who in his turn folded his arms and stared at the grocer, who stood at his door and yawned at the chemist. The watchmaker, always poring over a little desk with a magnifying-glass at his eye, and always inspected by a group of smock-frocks poring over him through the glass of his shop-window, seemed to be about the only person in the High-street whose trade engaged his attention. (68) 
Notwithstanding the fact that Pip observes this in the early morning in what is probably not a large market town, the accent of the image is characteristically Dickensian: the middle classes not working very hard. This is not the conventional Victorian picture of a nation engaged in industrious pursuits of wealth, but a cartoonish image of a pervasive social dynamic promoting idleness and snobbery even in places of the nominal primacy of work. The focal point of this image is the concern with one's place in the hierarchy of social capital, and an anxiety that the place might be compromised by those one considers to be closely below in social status (that is why the catalogue of the shopkeepers here is also somewhat suggestive of the social hierarchy among them). Pumblechook is at the top of this hierarchy; when he is first introduced in the story, Pip says of him that he "was a well-to-do corn-chandler in the nearest town, and drove his own chaisecart" (41-42); ${ }^{13}$ Pumblechook regards himself as being occupied in a "genteel trade;" the coachmaker and the saddler make things that may be associated with genteel lifestyles; the baker, grocer and chemist cater to a broader public purchasing general necessities. The watchmaker is comically rendered as the only exception to this logic of concern with status rather than work ("the only person in the High Street whose trade engaged his attention"). A group of the poor (designated by Pip's contemptuous metonymy as "smock-frocks") looking at the watchmaker work inscribe the passage with another logic of looking: of the poor looking in fascination at those above them in social hierarchy - in an interpretation concerned with satire in the passage it could be proposed that the poor are observing in amazement the only shopkeeper who seems to be actually working; in a more technical interpretation, the object of their fascination could be the technical aspect of the watchmaker's craft, or the very economic value of the timepieces he makes, or the growing social importance of timekeeping in the operations of the contemporary world. At any rate, the drift of the passage

13 Once Pumblechook begins to think (as Pip is getting ready to move to London) that Pip may have access to large amounts of money, he wants to get Pip interested in his business: "By degrees he fell to reposing such great confidence in me, as to ask my advice in reference to his own affairs. He mentioned that there was an opportunity for a great amalgamation and monopoly of the corn and seed trade on those premises, if enlarged, such as had never occurred before in that or any other neighbourhood. What alone was wanting to the realization of a vast fortune, he considered to be More Capital" (155-156). Perhaps it could be hypothesized that Pumblechook's very business may be an allusion to Corn Laws. P.J. Cain and A.G. Hopkins noted that "[ $\mathrm{t}]$ he Corn Law of 1815 [...] was a wholly conservative affair that reflected the assumption that agriculture and the landed interest remained central to the economy and society" (2001: 82). Pumblechook's attempt to get Pip interested in his business plans is meant to be dated some years after the passing of the law (in his article on the novel's chronology Meckier dates Pip's departure for London to 1823; p.169). The narrative does not indicate how Pumblechook's business, which is not extensive, may have been influenced by the agrarian protectionism of the Corn Law, or what the business opportunity he mentions to Pip is. However, what is clear is that Pumblechook is featured as a thorough toady and opportunist concerned with status and hierarchy, and eager to exploit social connections to get access to capital (which he expects to get from Pip). 
is that not much actual work is done in this segment of middle-class society, and no great intensity of circulation of economic capital is to be observed; what does seem to circulate in abundance is anxiety about social capital.

If the small-business men keep an eye on each other fearful of possible disturbances to the local social order, Herbert Pocket is engaged in another kind of looking, supposedly for career opportunities as a "capitalist - an Insurer of Ships." The list of his business plans is a lengthy one: "'I shall not rest satisfied with merely employing my capital in insuring ships. I shall buy up some good Life Assurance shares, and cut into the Direction. I shall also do a little in the mining way. None of these things will interfere with my chartering a few thousand tons on my own account. I think I shall trade [...] to the East Indies, for silks, shawls, spices, dyes, drugs, and precious woods." He also plans to trade to the West Indies and Ceylon, all of which makes Pip conclude that "You will want a good many ships." When Pip asks him "where the ships he insured mostly traded to at present?" Herbert explains his position in the City: "I haven't begun insuring yet [...] I am in a counting-house, and looking about me" (179). After pursuing the activity of looking about him for a while Herbert expects that "Then the time comes [...] when you see your opening. And you go in, and you swoop upon it and you make your capital [...] When you have once made your capital, you have nothing to do but employ it" (180).

The phrase - looking about - sums up Herbert's simple understanding of how to make money in the City (mostly through investing on the stock market and engaging in profitable global trade, i.e. his looking about is a speculative activity). The obstacle that stands in the way of these expectations is that Herbert lacks any disposable capital, a problem to be solved by his "looking about." Upon hearing that Herbert's ambition is to become a capitalist, Pip is somewhat sceptical (an impression from earlier in their conversation returns to him "that Herbert Pocket would never be very successful or very rich" 179). Later in their acquaintance, he notes that Herbert's situation in the counting-house does not amount to much: "I do not remember that I ever saw him do anything else but look about him" (258) at the counting-house; regarding its physical location Pip observes dryly that it was not "a good Observatory" (181). That Herbert's "poverty" (180) is not to be removed by his "looking about" him serves a dual purpose in the narrative: on the one hand, it dramatizes Herbert's activities in the City, such as they are, as derivative reflections of an ideology that informs the operations of much higher echelons of financial power, with Herbert here appearing but a lowly apprentice enchanted by the ideology of readily available opportunities and profit. On the other hand, the failure of his "looking about" him makes it clear that his trust in the ampleness of economic opportunity is not built on a solid foundation, for he possesses neither business savvy (which his assumed habitus requires) nor any amount of disposable capital. Needless to say, Herbert's naïve belief in the "tremendous" profits (179) is one of the numerous contemporary middle-class novelistic cautionary tales about the moral dubiousness of speculation, and acquisition of wealth without work. The small-business men in the market town look around them as a way of surveilling and defending their social positions, 
and Herbert looks about him supposedly to advance his economic position. What brings these two strands of narrative together is the absence of actual work: Pumblechook and the shopkeepers from the market town (except for the watchmaker) as well as Herbert are effectively idle, all presumably men of business. This infuses the narrative with a peculiarly Dickensian point of view: the national, imperial and global economies where tremendous wealth is generated are featured as distant, fabled domains in contrast to the narrative close-up on idleness, status aspirations, snobbery, waste of energies and money, crime and poverty, which surround the lives of the characters in the novel.

\section{Certain lands of considerable value}

From another angle, it could be said that the narrative is set in the zone of contact between poverty and affluence, an area of social life that contemporary middle-class literature found interesting as a context for plots of social mobility. In this regard, the novel is concerned with problematizing the notion of personal application as an instrument of creating wealth, ${ }^{14}$ as much as with constructing stories that involve other forms of acquisition and circulation of wealth. Magwitch's journey from poverty to wealth is not featured as an unconvincing, sensationalist plot device, but rather as a realistically possible turn of events exemplifying personal effort and facilitated by the framework of the British Empire. Late in the novel Pip avails himself of the broad extent of British commercial power, and acquires some moderate wealth, which is certainly not the result of his newly discovered industry only. The narrative is carefully structured at this juncture to outline a flow of gifts: the money with which Pip gets a position for Herbert (who does not know about his interference) with Clarriker's is of course the money that came from his unknown benefactor Magwitch. However, Pip's arrangement with Clarriker involves several payments, and after learning the identity of his patron, Pip eventually completes the arrangement with the money that he asks and gets from Miss Havisham for the purpose. Later, Pip joins Clarriker's branch house in Egypt, where Herbert is in charge, and after "[m]any a year" becomes

a partner in the House [...] I must not leave it to be supposed that we were ever a great House, or that we made mints of money. We were not in a grand way of business, but we had a good name, and worked for our profits, and

14 Jerome Meckier (in an article published in 2001) interpreted Great Expectations as a "parodic deflation of David Copperfield" (2001: 539); that is, Great Expectations was Dickens's attempt to revaluate the emphasis on self-help and perseverance in David Copperfield by criticising (implicitly) the tone that shaped Samuel Smiles's book Self-Help (1859). In this regard, Meckier argues that "[ $[\mathrm{t}]$ hroughout Great Expectations, Dickens equates the impulse toward self-improvement with base cravings for social and material advance" (2001: 543). Even though in the novel Smiles is not "the explicit target" (2001: 539), the novel was a critique of the spirit informing Smiles's book and "the Victorian era's cultural myth [...]; the country's exalted view of itself as a civilization continuously in the ascent" (2001: 551). 
did very well. We owed so much to Herbert's ever cheerful industry and readiness, that I often wondered how I had conceived that old idea of his inaptitude, until I was one day enlightened by the reflection, that perhaps the inaptitude had never been in him at all, but had been in me. (436)

While this affirmation of the value of industry and hard work (and a reappraisal of the way in which he previously thought of Herbert) is a continuation of the melodramatic change in his views on the issues of wealth and work that Pip has upon Magwitch's return (he decides not to receive Magwitch's money any longer), the bottom line is that the money that came from Magwitch turns out to form the launch pad for Herbert's career at Clarriker's, that Miss Havisham's money is also needed to complete Pip's deal with Clarriker, and that Herbert's position with the company becomes the foundation for Pip's professional career.

Magwitch's account of his life in Australia is rigorously constructed to reinforce the general thematization of the generation of wealth in the novel. When on their reunion late in the novel the dumbfounded Pip enquires "How are you living?", Magwitch's first answer is: "I've been a sheep-farmer, stock-breeder, other trades besides, away in the new world [...] I've done wonderfully well. There's others went out alonger me as has done well too, but no man has done nigh as well as me. I'm famous for it" (296). In a way, it may seem that Magwitch's Australian life is an exemplary story of self-help, and possibly suggestive of his moral reform and social integration. While it is clear here that he was "famous" in Australia for his wealth, the rest of his account makes it clear that this fame did not mean that he was accorded higher stratus in the colonial society. In fact, though the text does not furnish much information on Magwitch after he got rich, it does suggest that his desire to repay Pip by providing him with the means of becoming a gentleman does not only have an English history, but an Australian history as well, insofar as Magwitch the wealthy former convict was treated in Australia as socially inferior by the "colonists:"

"[...] dear boy, it was a recompense to me, look'ee here, to know in secret that I was making a gentleman. The blood horses of them colonists might fling up the dust over me as I was walking; what do I say? I says to myself, 'I'm making a better gentleman nor ever you'll be!' When one of 'em says to another, 'He was a convict, a few year ago, and is a ignorant common fellow now, for all he's lucky,' what do I say? I says to myself, 'If I ain't a gentleman, nor yet ain't got no learning, I'm the owner of such. All on you owns stock and land; which on you owns a brought-up London gentleman?" (299) ${ }^{15}$

15 Magwitch's reference to the "colonists" can be regarded as resonant also with the mid-century period, when a local genteel elite was being formed in Australia based in part on the British model. In his book Ornamentalism, David Cannadine points out that "[f]or much of the second quarter of the nineteenth century, when British agriculture was generally depressed [...] sprigs of nobility and distant cousins set off for Canada, New Zealand and Australia, in the hope they might establish and enjoy the sort of genteel life there on which they could no longer count on in Britain [...] It was the same elsewhere in the Antipodes, where British models of gentility and hierarchy were energetically replicated and enthusiastically reproduced. In Victoria, South Australia 
Magwitch's English history and his Australian history are informed by a sense of hierarchical social relations connecting the two locations. ${ }^{16}$ To what extent is Magwitch's story resonant with the actual situation in Australia in the second and third decades of the $19^{\text {th }}$ century, during which period it probably takes place, ${ }^{17}$ is an interesting question. The "colonists" Magwitch mentions may be free settlers, or possibly officers in the British military forces, or colonial civil servants; they are represented as wealthy land-owners in Australia ("All on you owns stock and land"). ${ }^{18}$ As for Magwitch's own accumulated Australian wealth, his account of his life in Australia suggests that his rise to riches was not solely the result of his hard work and perseverance (or of some sort of personal reinvention in the new world), but that it also had something to do with giftgiving. Magwitch lets Pip know that at first he "was a hired-out shepherd in a solitary hut," and adds a little later that: "From that there hut and that there hiring-out, I got money left me by my master (which died, and had been the same as me), and got my liberty and went for myself. [...] It was the money left me, and the gains of the first few year wot I sent home to Mr. Jaggers-all for you - when he first come arter you [...]" (299). Thus, Magwitch's early fortune in Australia did not exclusively proceed from self-reliance, since some of it was a gift from his master (also a former convict, whose story is untold); the money that Magwitch transfers to Pip therefore originated in part in this initial act of gift-giving that helps propel Magwitch's rise. Furthermore, Magwitch drops a

and Tasmania, successful early settlers purchased and extended large estates in the midVictorian period [...]" (2001: 28-29). As for Magwitch's resentment of the "colonists," it evokes the early history of New South Wales. Speaking of the colony at the beginning of the 19th century, Stuart Macintyre states that "division between the 'exclusives' and the 'emancipists' - those who came free and those who were transported - troubled all aspects of public life in a confined, intimate society and persisted into the next generation and beyond until the numbers and attitudes of the 'native born' finally prevailed" (2009: 43-44).

16 Patrick Brantlinger remarked on the passage: "According to Magwitch's thinking, a free 'colonist' riding a 'blood horse' may be his superior in Australia, but 'a brought-up London gentleman' is superior to any 'colonist,' convict or free" (2009: 112). A noteworthy aspect of this situation, as Brantlinger points out, is that Pip's superior London status comes "from the work and wealth-production that take place in the colonies" (2009: 112).

17 Janice Carlisle sums up Jerome Meckier's reconstruction of the novel's chronology: "its main action spans the period from the beginning of 1812, when Pip is about seven years old, and late June 1829" (1996: 5), before Pip's departure for Egypt to work for Clarriker's. This also helps date the period of Magwitch's life in Australia.

18 In Magwitch's time, ownership of land in the colonial society was markedly uneven as a result of land grant policies. In The Cambridge History of Australia. Volume 1 (edited by Alison Bashford and Stuart Macintyre), Grace Karskens mentions that ex-convicts "[b]y 1821 [...] grew most of the colony's grain, owned over two-thirds of land under cultivation, half the cattle and a third of the sheep in the colony. [...] Free settlers (including civil and military officers) who made up only 17 per cent of all the landholders, held 57 per cent of the alienated land" (2013: 104). 
hint that some of the money he made may have come from speculation ("I swore [...], sure as ever I spec'lated and got rich, you should get rich" 297), although we do not learn precisely how he speculated, or at what point in the process of getting rich. Interestingly enough, Magwitch's wealth seems to exemplify a wide range of possible sources of wealth in $19^{\text {th }}$ century Britain and its empire: hard work, inheritance, and speculation; even land, for he owns in Australia "certain lands of considerable value" (408). ${ }^{19}$ Making possible all of Magwitch's Australian accumulation is the very fact of colonialism.

In light of all this, it bears reiterating that the narrative does not seek to build Magwitch into a model of hard work and self-making embodying the kind of social habitus the middle classes should advocate or the poor aspire to. Furthermore, his project of making Pip into a gentleman is driven by the idea that Pip should be above work, and that he should be sufficiently well off to engage in such aspects of a genteel lifestyle as are quite irreconcilable with the ethics of hard work: "You shall show money with lords for wagers, and beat 'em!" (298). In contrast to the sensationalist turning point of the scene in which Pip comes to a recognition of his actual circumstances (that his money comes from Magwitch), the story makes it clear that Magwitch himself does not fully illustrate the lesson that Pip is supposedly learning afterwards, that of having to make a fortune for oneself by hard work alone. ${ }^{20}$ And it is also clear that the effects of Magwitch's

19 Just as we do not know about Magwitch's speculations, there is also no direct explanation in the narrative on how or why Magwitch acquired the land, but it is most likely to be regarded as an investment to extend his wealth. In the early history of the colony, ex-convicts received small grants of land from the British colonial administration (see Macintyre 2009: 37, 47); however, the mention of "considerable value" of the lands that Magwitch owned suggests that he probably acquired the lands as part of his enterprising activities.

20 According to Meckier, Magwitch is a "severest caricature of self-helper" in the novel, and "a ruthless adherent to Smilesian principles;" in his pursuit of profit in Australia Magwitch is an embodiment of perseverance and exceptional determination. Meckier stresses that Magwitch's version of perseverance is problematic in the novel for its motivation, informed as it is by the goal of getting even, through making Pip into a gentleman, with the society that marginalized him: "thanks to a system that neglected, then punished him, Magwitch lacks a lofty ideal, a worthier goal than revenge (2001: 548). Alluding to the opportunities offered by the colony, Meckier points out the irony of the fact that getting transported "is the only good thing that England's social system ever does for Magwitch;" he also notes that in Australia Magwitch was "left money by his master" (2001: 549). But while Meckier in effect focuses on Magwitch's perseverance in creating his wealth in Australia, I want to stress that it is important to take into account the narrative association of Magwitch's wealth also with inheritance and speculation, as well as with the specific context of the colony, all of which suggests that Dickens is careful not to attribute his wealth to perseverance alone. In this way the novel underscores its reservations about the ideological persuasiveness of stories of accumulating substantial wealth exclusively through hard work. The goal of Magwitch's perseverance, which is driven by his resentment against the genteel elite, is also expressive of his indirect acceptance of its social prestige-for he wants to make Pip a gentleman. 
gift of money in the narrative continue to affect Pip's social status even after Pip no longer has any intention to benefit financially from his wealth.

Magwitch's gift of money to Pip is a return gift for Pip's gift of food, brandy and a file to him; the narrative abounds in acts of gift-giving. ${ }^{21}$ Pip covertly gives money to Clarriker so that Herbert could get a job; Herbert's invitation to Pip to work for Clarriker's is a favour with financial consequences. Some of the gifts in the narrative are inheritances: Magwitch inherits his master's money, Estella inherits most of Miss Havisham's property, and Matthew Pocket inherits some of her money. It should be stressed that the motif of gifts and inheritances in the narrative eclipses questions of the generation of wealth, advertising instead the narrative concern with transfer of wealth. This seems to serve two narrative purposes: in the first place, a critique of the popular middle-class rhetoric of selfhelp. Not that there aren't any characters in the novel who appear unambiguous embodiments of self-reliance; after all, Biddy and Joe do not benefit from gifts, inheritances or social connections, and quietly and modestly improve their situation through their own efforts (Joe is described early as having "a strong sense of the virtue of industry" p. 114; he does well enough to be able to settle one of Pip's debts, and Biddy becomes a mistress in a newly built school; also, Joe finally learns to write thanks to Biddy). ${ }^{22}$ On the other hand, neither Herbert nor Pip can be said to exemplify unambiguously the principle of self-help. Secondly, the motif of gifts seems to provide some of the armature of the novel's symbolic economies of moral reward; for instance, Joe informs Pip that Miss Havisham, other than leaving most of her property to Estella, wrote a codicil "in her own hand [...] leaving a cool four thousand to Mr. Matthew Pocket," whereas one of the other relatives, Camilla, 'she have five pound fur to buy rushlights to put her in spirits when she wake up in the night'” (423). The inheritance left to Camilla is meant as something of a facetious slight, since Miss Havisham did not care much for Camilla's outpourings of concern. Her will indirectly evokes her father's moral dilemmas about his will; after disinheriting his son for dissolute behavior, he "softened when he was dying, and left him well off, though not nearly so well

${ }^{21}$ For a detailed discussion of the theme of gift-giving in the novel see Vincent P. Pecora's article "Inheritances, Gifts, and Expectations" (2008). Pecora's article evokes the context of contemporary testamentary law: under English law it was possible to dispose of one's property in one's will with fewer restrictions than in continental systems of law. Miss Havisham's relatives, described as toadies, try to avail themselves of such opportunities. Also, Pecora relates the theme of gifts and inheritances to generosity as "the moral master-key to all of Dickens's writing" (2008: 179).

22 Meckier emphasizes "Joe's refusal to raise himself or to be raised by Pip" (2001: 543). Before departing for London Pip expresses to Biddy his intention "to remove Joe into a higher sphere" (Dickens, p. 150), as well as a snobbish concern about Joe's manners. Joe, on the other hand, quietly declines in the rest of the narrative to profit socially from Pip's rise. Meckier claims that "[w]ith Joe's reservations about raising himself, Dickens parodied the reigning definition of self-improvement" (2001: 548), meaning the Smilesian one. Of course, Joe, and Biddy as well, also embody a version of selfimprovement, the one which the novel seems to promote. 
off as Miss Havisham" (176). In the structure of the narrative Arthur Havisham's dissolute behaviour in turn resembles (though it is not of the same kind as) Pip's cavalier ability to fritter away much of the financial resources provided for him by Magwitch.

Gifts happen in the novel for a variety of reasons. Pip's gift of food, brandy and a file to Magwitch is not voluntary. Magwitch's plan to make Pip a gentleman is a return gift to Pip as well as a way of vicariously resolving his grievances against the genteel classes in both English and colonial society. Pip's getting Herbert a position at Clarriker's, conceived in the spirit of friendship, is based on the money that he gets from his unknown patron; the arrangement with Clarriker is completed with the gift of money that Pip receives from a remorseful Miss Havisham. On getting Clarriker the cheque, Pip states: "It was the only good thing I had done, and the only completed thing I had done, since I was first apprised of my great expectations" (380). Herbert invites Pip to join him at Clarriker's as a clerk (409); it is an act constructed in the narrative as proceeding from Herbert's sense of friendship (it cannot be regarded as repayment, since at this time he does not know how he got the job). Miss Havisham tells Pip that at first she only "meant to save [Estella] from misery like my own," 366), but later she tried to shape Estella as her instrument for a specific purpose; as Herbert states, Estella "has been brought up by Miss Havisham to wreak revenge on all the male sex" (173). Miss Havisham's leaving a "cool" sum of money to Herbert's father is a form of expiation for her treatment of him (she and Matthew Pocket parted ways after he advised her against Compeyson a long time ago). Gifts are used differently: Pip mostly dissipates the money provided by Magwitch throughout much of his London life as a gentleman, but Herbert capitalizes on getting a position with Clarriker's, and makes good use of it. Pip's squandering of Magwitch's money is in some way productive of the kind of social prestige that Magwitch thinks of as gentlemanly - he tells Pip that he came back to England "fur to see my gentleman spend his money like a gentleman" (307), but this is the kind of understanding of social capital that the narrative works to eventually reject. On the other hand, Pip's purchasing a position for Herbert with Clarriker's illustrates the process of economic capital being transformed into more economic capital, for Clarriker's is later said to do "very well."

Perhaps, as Vincent P. Pecora suggests, the giving of gifts is central to Dickens's notion of generosity as a corrective social practice "in a society built on individual self-aggrandizement" (2008: 185). In Pecora's view, "Dickens is careful to demonstrate that gifts, inheritances, and the expectations that come with them are an integral and potentially ennobling part of social life" (2008: 183). ${ }^{23}$ In the

${ }^{23}$ In Pecora's reading, the narrative of "Pip's great expectations" is intertwined with a story of his "lesser expectations: the unbroken chain of gifts and return gifts [...] that in the end provides the fundamental social glue in Dickens's otherwise grasping and swindling pre-Victorian society (the novel [...] is set in the era of Dickens's childhood)" (2008: 184). 
relationship between Pip and Herbert the narrative indeed stresses the element of generosity, where both Pip's getting Herbert a job and Herbert's inviting Pip to join him at Clarriker's are constructed as generous acts not conceived in expectations of reciprocity; however, these acts of gift-giving also turn out to be instruments of middle-class solidarity, forming a resource of social capital for Pip. Joe's nursing Pip back to health and the settling of a debt of his (despite some earlier instances of Pip's condescension) is an emphatically altruistic act of gift-giving that arguably stands apart from most other gifts the way that Joe stands apart from the lure of class aspirations. At the same time, gift-giving is also a source of anxiety and confusion about what kind of ideological articulation should be accorded to it as well as about what its effects are (primarily the effects of the ill-conceived gifts of genteel status bestowed on Pip by Magwitch and on Estella by Miss Havisham). In this regard, while Pip eventually gives up his status aspirations (which are supported by Magwitch's gift of money) for hard work, the narrative generates ideological discomfort about its own plot by the fact that Magwitch's initial gift of money sets in motion a conversion of economic capital into social capital that endures for Pip even after he renounces Magwitch's money.

Interestingly enough, after Magwitch's arrest Pip explains his resolution not to attempt to make any claim on Magwitch's property in terms of a realistic assessment of the legal situation as well as personal convenience (his decision not to accept Magwitch's money any more has already happened soon after Magwitch's return): $:^{24}$

I imparted to Mr. Jaggers my design of keeping [Magwitch] in ignorance of the fate of his wealth. Mr. Jaggers was querulous and angry with me for having "let it slip through my fingers," and said we must memorialise by and by, and try at all events for some of it. But he did not conceal from me that, although there might be many cases in which the forfeiture would not be exacted, there were no circumstances in this case to make it one of them. I understood that very well. I was not related to the outlaw, or connected with him by any recognizable tie; he had put his hand to no writing or settlement in my favour before his apprehension, and to do so now would be idle. I had no claim, and I finally resolved, and ever afterwards abided by the resolution, that my heart should never be sickened with the hopeless task of attempting to establish one. (408)

It is of course only through Pip's having to work for a living that his dissociation from Magwitch's money becomes fully effective as an ideological shift in his

24 In a conversation with Herbert after Magwitch's return Pip contemplates what it would mean for him not to continue to benefit from Magwitch's money, since he is "bred to no calling, and fit for nothing" (316), but he informs Herbert that he has resolved not to take any more money from Magwitch. The subject of Pip's intentions regarding Magwitch's wealth comes up again when Wemmick lets Pip know that Magwitch's arrival to London may no longer be a secret, and advises Pip to "lay hold of his portable property" (342), but Pip does not tell Wemmick that his mind is already made up on this. 
attitudes to wealth. However, the narrative cannot undo the fact that Magwitch's gift to Pip is measured not just in terms of the money that Pip received or might have enjoyed, but also in terms of the social connections created by his life in London, made possible by Magwitch. The social capital (of a "brought-up London gentleman," to use Magwitch's words) that Pip enjoys at the end of the novel is good enough to eventually get him a position at Clarriker's, the company whose business has benefitted from Magwitch's and Miss Havisham's money. ${ }^{25}$

\section{The spurious coin}

It is worth remembering that money forms a prominent medium of Pip's self-imagination. In an episode halfway in the story he decides to stay at an inn instead of staying at Joe's on a visit to his home town (and explains the choice to himself as a matter of convenience); the narrating Pip characterizes the decision as self-deception:

All other swindlers upon earth are nothing to the self-swindlers, and with such pretences did I cheat myself. Surely a curious thing. That I should innocently take a bad half-crown of somebody else's manufacture is reasonable enough; but that I should knowingly reckon the spurious coin of my own make as good money! An obliging stranger, under pretence of compactly folding up my bank-notes for security's sake, abstracts the notes and gives me nutshells; but what is his sleight of hand to mine, when I fold up my own nutshells and pass them on myself as notes! (216)

Pip's couching his description of his dishonesty to himself in terms of financial swindling anticipates the revelation later in the novel that Magwitch had been recruited by Compeyson to help him in "swindling, handwriting forging, stolen bank-note passing." The financial swindling in which Compeyson is engaged is a theme placed on the margins of the narrative, but it is still a significant evocation of uncertainties associated with use of paper money. ${ }^{26}$ Pip evokes the monetary

25 After Magwitch's death Pip contemplates the idea of talking to Biddy about a life together and having her decide "whether I shall work at the forge with Joe, or whether I shall try for any different occupation down in this country, or whether we shall go away to a distant place where opportunity awaits me" (429), before finding out that Biddy is married to Joe-a turn of the plot after which Pip leaves England to join Herbert at Clarriker and Co. in the East, emphasizing precisely that Pip does eventually benefit from the flow of capital initiated by Magwitch's money.

26 Mary Poovey's study of "genres of the credit economy" furnishes an interesting perspective on the relationship between financial writing, monetary genres (money as inscription), and literature in Britain in the $18^{\text {th }}$ and $19^{\text {th }}$ centuries. In discussing bank paper as one of the monetary genres, Poovey observes that the Bank Act of 1844 "began to rationalize the English banking system, to make the Bank of England notes the most stable (and therefore desirable) form of paper currency, and to make information about the currency regularly available to anyone who wanted it" (2008: 163). Poovey observes that in the previous period the Bank Restriction Act of 1797 "caused the number of country banks to explode and the volume of their note issue to swell" 
idiom as part of an act of self-analysis; Steven Connor interpreted Pip's selfswindling in terms of a psychoanalytic understanding of the decentred self, and of an interplay between consciousness and repression which forms much of the dynamic of Pip's narration. ${ }^{27}$ Pip's account of his self-swindling in this episode indeed exemplifies the narrative's construction of a complex idea of self. Pip observes here that he "knowingly" engaged in self-deception; the tone of his self-analysis and the use of the metaphor of financial swindling (which are meant to suggest self-reproach) reveal his irritation that he engaged in self-deception despite understanding its motivation, while the very act of the self-criticism may be read as a measure of his adoption of a reformed moral perspective. Interestingly, on another occasion Pip comments on the overall theme of his narrative, his great expectations, and articulates rather clearly the notion of a divided self: "As I had grown accustomed to my expectations, I had insensibly begun to notice their effect upon myself and those around me. Their influence on my own character I disguised from my recognition as much as possible, but I knew very well that it was not all good" (256). The narrating Pip is in possession of an understanding of the mechanisms of his own pretences, but so is occasionally the experiencing Pip as he struggles with his social aspirations.

The above passage about self-swindling can also be seen as a brief reference to perplexing aspects of money (How is good money different from spurious

(2008: 47). It was only with introduction of a new printing technology by the Bank of England in 1855 "that identical notes could be produced" (2008: 49). In an article on the search by the Bank of England, in the 1797-1821 period, for banknote design and production that would result in "an inimitable note" (197) and thus prevent extensive counterfeiting (the search was abandoned in 1821), Virginia Hewitt mentions that at that time "distributing forged notes, as well as the act of forgery were capital offences, and the penalty for simply possessing a counterfeit note was fourteen years transportation" (1998: 203). In the trial "on a charge of putting stolen notes in circulation - and there was other charges behind," Magwitch gets a sentence of fourteen years. While the novel provides little detail on Compeyson's swindling (it is unclear for instance what was involved in "handwriting forging"), it evokes the potential for fraud attendant on increasing use of paper money at the beginning of the century.

27 Connor analyzed Pip's self-swindling in terms both of a Lacanian understanding of self but also in the context of "the sort of society in which Pip is growing" (1985: 142). In this regard, Connor associated Pip's formation with capitalism: “The economic world in which Pip eventually finds respectability is of course a capitalist one [...] The capitalist world is a world of fluctuating value and unattached signifiers, a world in which authenticity, unity and honesty are systematically made impossible" (1985: 143). Ultimately, Connor argued, Pip's accommodation to this world involves a sort of compromise: "He does not withdraw from social and economic relations altogether, nor does he seek to exploit them" (1985: 144). Although Dickens is certainly careful not to present Pip's company as being engaged "in a grand way of business," the company clearly functions within the context of British commercial power. My analysis dwells not so much on general aspects of the relationship between capital and self in the narrative, but on a more specific ideological relationship and compromise: between wealth conferred as a gift and wealth acquired through hard work. 
money? What creates the foundation of trust in exchanges involving paper money, or money in general for that matter? The passage implicitly raises such questions, evoking the role of social constructions of power and trust that underwrite the very functioning of money and credit). In addition to conveying a puzzlement over the functioning of money in general, as well as highlighting the motif of the shady circulation of counterfeit value, Pip's use of the monetary metaphor in this act of self-analysis also brings up the theme of a colonization of the personal by the economic: self-perception receives articulation in terms of financial exchanges. In this way the passage also refers back to the name Pumblechook uses for Pip; incidentally, Pumblechook is described by Pip as the "basest of swindlers" (111), possibly for seeking to profit from Pip's relationship with Miss Havisham. Dickens's emphasis on the centrality of the monetary economy to the construction of self calls attention to the role of money in mechanisms both of objectification of characters (Pumblechook's ascription of a monetary value to Pip), as well as their subjectivation (the internalization of economic discourse itself in Pip's self-imagination).

Finally, money is not the only form of capital in the narrative world; social status as a serviceable form of capital is among the narrative's main concerns. Throughout most of his career as a gentleman Pip lives on someone else's money, and his (mis)management of it leads him to a steady contraction of debt, ${ }^{28}$ which is in turn made possible precisely by his being perceived as possessing a gentlemanly status. The mutual interplay of status, money and debt appears in the narrative as a profound moral problem, associated with the corruption of the middle classes by the social influence of the ideology of gentility. ${ }^{29}$ The generation of Pip's spending power and especially the power of spending beyond his means is predicated on his gentlemanly image among his creditors; the narrative seeks to strongly ridicule and condemn Pip's "business habits" both as a form of selfdeception ${ }^{30}$ and as an expression of a credit economy in which social capital can go

28 " [...] I began to contract a quantity of debt. I could hardly begin but Herbert must begin too, so he soon followed. At Startop's suggestion, we put ourselves down for election into a club called The Finches of the Grove: the object of which institution I have never divined, if it were not that the members should dine expensively once a fortnight, to quarrel among themselves as much as possible after dinner, and to cause six waiters to get drunk on the stairs. [...] The Finches spent their money foolishly [...]" (257).

29 Q.D. Leavis argued that Pip's "feelings are by no means that of a snob" (1970: 304), and suggested that the notion of gentleman is still an operative measure of social distinction in the novel: "Dickens undoubtedly believed that there was respectable content in the idea of gentleman" (1970: 298). In her view, Herbert is set apart from the society of characters like Pumblechook from the market town. The narrative certainly differentiates between different characters with status aspirations, but it also satirizes the appeal of the ideology of gentility as the basis for social distinction.

30 Pip develops his own method of accounting which allows him to contract ever more debt: "My business habits had one other bright feature, which I called 'leaving a Margin.' For example; supposing Herbert's debts to be one hundred and sixty-four pounds four-and-twopence, I would say, "Leave a margin, and put them down at two 
a long way in supplementing one's financial resources. The conventional middleclass inflection of the novel's moral conclusions comes through particularly in the episode in which Joe, who stands completely outside the social world to which Pip belongs as a gentleman, settles a debt for Pip after Pip can no longer count on Magwitch's money: the moral lesson is of course that Joe's unpretentious but steadfast hard work results in the creation of (however modest) surplus capital, whereas Pip's idleness and social pretence was capable only of creating debt.

Thus we come to two intertwined narrative drifts which coexist not altogether comfortably. On the one hand, Pip's story plays out as a melodrama which is set in motion by his ambition of rising above his initial social status; much of his subsequent period in London is spent in disorientation and dissipation, and ultimately Pip must learn to overcome his self-swindling and dissociate himself from the social pretence born out of his genteel aspirations. On the other hand, the narrative does construct for its protagonist a way to rise above his original social circumstances, and this way is built on the effects of Magwitch's money, so that it ultimately does count (just as Miss Havisham's money does too). Facing (relative) poverty with an ethic of hard work and self-improvement (embodied by Joe and Biddy) is indeed worked into the narrative as an ideologically desirable habitus, something that the text advertises to its readers. On one occasion, after Biddy joins the Gargery household ("with a small speckled box containing the whole of her worldly effects" 128) to care for Pip's sister after she was attacked, Pip tells her: "You are one of those, Biddy [...] who make the most of every chance. You never had a chance before you came here, and see how improved you are!" (130) In contrast to Biddy's steady pursuit of self-improvement over the years (after Mrs. Joe Gargery dies, Biddy tells Pip of her plan to get a position as a mistress in a school: "I hope I can be industrious and patient, and teach myself while I teach others" 265), Pip's story goes through the elaborate melodramatic architecture of his great expectations, constructed by his being given the opportunity of rapid social mobility, to embracing an ethic of hard work, an opportunity that comes to him because of his possession of social capital.

The novel does not seek to present a detailed understanding of how wealth and poverty come about in the represented world; it is not an extensive study of either rural or urban poverty, or of landed, financial, mercantile or industrial wealth. Its perspective is fragmentary, even as the fragments and elisions are arranged in such a way as to evoke much historical detail and important historical contexts. And its perspective is about the present rather than the past, as Humphry House argued: "[ $t$ ]he mood of the book belongs not to the imaginary date of its plot, but to the time in which it was written; for the unquestioned assumptions

hundred." Or, supposing my own to be four times as much, I would leave a margin, and put them down at seven hundred. I had the highest opinion of the wisdom of this same Margin, but I am bound to acknowledge that on looking back, I deem it to have been an expensive device. For, we always ran into new debt immediately, to the full extent of the margin, and sometimes, in the sense of freedom and solvency it imparted, got pretty far on into another margin" (260). 
that Pip can be transformed by money and the minor graces it can buy [...] were only possible in a country secure in its internal economy, with expanding markets abroad: this could hardly be said of England in the "twenties and "thirties" (1950: 159). The novel's engagement with the contemporary period has to do with the theme of the corrosive appeal of class hierarchy and of money without work, which is not meant simply as examination of some distant, waning aspects of society; in fact, that these temptations are central to the contemporary middle class may be said to be the anxiety informing much of the ideological work of Dickens's narratives, this one included. However, in contrast to House's claim that "the book is the sincere, uncritical expression of a time when the whole class-drift was upward" (1950: 157), it should be noted that the novel dramatizes a fascination with social mobility as well as a discontent with the entire social system of hierarchy that serves as the frame for both class distinction and mobility.

In this dual dynamic of fascination and discontent, the economic world of England as imagined by the novel does not appear as being simply secure in itself; rather, it is a world of some degree of settled affluence but not of new productivity; a world not of accumulation of capital, but of accumulated capital; besides, some of the accumulated capital comes from somewhere else. In this context, Pip's early relationship to the world, expressed in the intertwining of his perception of the "picturesque" with possession of wealth and status (or a pursuit of social mobility), is featured as an ideological fantasy in the service of the maintenance of a hierarchical social structure. If Pip as a child is only vaguely aware of the vast network of British power and trade, which is metonymically evoked by the ships he regards as "picturesque," Magwitch's patronage of Pip inscribes a familiar tale of revenues of empire supporting genteel aspirations at home. Interestingly, Pip eventually makes money in the East ("I work pretty hard for a sufficient living") but the narrative is inconclusive regarding the question of his future residence (up to that point Pip still does not own a home, and lives with Herbert and Clara in Egypt), although there is some indication that it might be in England. In the concluding scene in the novel Pip comes across Estella at the site of Satis House and the brewery, and it turns out that this is the only possession Estella still has. There is just "the wall of the old garden" left standing; the site is a "cleared space [...] enclosed with a rough fence" (437), and we learn that it is "to be built on" (439). The novel leaves open the possibility that the new construction might become part of the context for a new relationship between Estella and Pip to be built on, without explicitly stating it. ${ }^{31}$ However, the erasure

31 After Miss Havisham's death, the furniture of Satis House is to be auctioned off, and "[t]he House itself was to be sold as old building materials and pulled down" (430). When Pip comes across Estella on the site after being away for eleven years, she tells him: "The ground belongs to me. It is the only possession I have not relinquished" (438). This would seem to suggest that the construction to be done on the site is Estella's project. Yet, some ambiguity in this regard is maintained as she tells Pip that she "came here to take leave of it before its change," and a little later that she "little thought [...] that I should take leave of you in taking leave of this spot" (439). Is she perhaps in the 
of the past of the site does not wholly erase the effects of the circulation of gifts in the narrative, and the legacies of Magwitch's wealth and Miss Havisham's wealth, however changed or diminished, reappear as the basis for a new order of things for Pip and Estella.

For all the massive economic activity and global power of England, the English middle-class world is presented in the novel as fraught by stagnation, caused by the lure of participation in a continuous renewal of the conservative order of social capital (embodied in the notion of gentility) and its mechanisms of hierarchy and mobility, and by the appeal of acquisition of wealth without work. Simultaneously, the narrative also calls into question the persuasiveness of the ideology of hard work and self-reliance that it declaratively endorses. Or rather, the narrative asks its readers to recognize that it seriously entertains this ideology only to a point, since patronage and access to social connections (which are Magwitch's gifts to Pip) are featured as social mechanisms centrally involved in the making of Pip's middle-class habitus, even as he strives to disencumber himself from fascination with social distinction without work. The novel also rejects excessive emphasis on material success as the objective of perseverance and application. The fact that Joe and Biddy are not overly or selfishly concerned with either status or material gains in their self-improvement points to an ideological space that does not overlap with that style of Victorian middle-class discourse that saw self-help merely as a path to economic and social mobility. Furthermore, it could be argued that an important target of the novel's work of irony is ideological emphasis on (economic) opportunity which goes hand in hand with the kind of middle-class notion of economic success that informs Herbert's early expectations. Looking about him (for opportunities) does not get Herbert very far, before Pip's intervention. Nor does Pip move up in social status without the assistance provided by Magwitch and Herbert (who initially introduces Pip to a gentlemanly life, and later to profitable work), as well as by Miss Havisham's eventually giving Pip money for Herbert's benefit. In this perspective, the narrative regards Herbert in his expectations of capital or Pip in his expectations of money and gentility as deserving of ridicule and criticism, but they are also eventually presented as pragmatists who make good use of their careers; opportunity comes to them not so much as a feature of the economic realm to be utilized by individual effort, but as a result of a circulation of capital not of their own making (at least until they start to work for a living). The novel makes this kind of pragmatism more comfortable for its middle-class readership by having the circulation of favours between Pip and Herbert proceed from a spirit of fellowship, which in effect functions as a form of middle-class solidarity.

process of selling the ground? Or is she taking leave of just the ruins of Satis House before the new construction, but not of the site itself? At the very least, the narrative thus breaks off not only with the question of whether the two would marry (Pip's suggestion is that they would, for he concludes the narrative by writing that he "saw the shadow of no parting from her" 439), but also with the question of whether they would live on the site where Satis House once stood. 
When Pip conspires with Wemmick to get Herbert a job without Herbert knowing of it, he reports "that we found a worthy young merchant or shippingbroker, not long established in business, who wanted intelligent help, and who wanted capital, and who in due course of time and receipt would want a partner" (279). As part of the arrangement the young shipping-broker, Clarriker, receives a sum of money and an obligation for future payments from Pip; Herbert would get a position and it is implied would eventually become partner. The company's business, which is connected with shipping, is not only a realization of Herbert's early fantasies of a capitalist career, but it also presents a reference to Pip's early fascination with ships (from the days on the marshes when he acted as Joe's tutor and watched the ships); the company turns out to be a link to the opportunities provided by the British role in global trade. Pip's joining the company is an attainment of his early hankerings after money, based on a development of a morally improved and pragmatically overhauled attitude to wealth and status. But what the novel thus also foregrounds is the significance of gifted wealth in the middle-class world, and the significance of capital to the creation of capital.

\section{Bibliography}

Bourdieu, Pierre (1987). "What Makes a Social Class? On The Theoretical and Practical Existence Of Groups." Berkeley Journal of Sociology 32, pp. 1-17.

Brooks, Peter (1976). The Melodramatic Imagination. Balzac, Henry James, Melodrama and the Mode of Excess. New Haven: Yale University Press.

Brooks, Peter (1984). Reading for the Plot. Design and Intention in Narrative. Cambridge: Harvard University Press,

Brantlinger, Patrick (2009). Victorian Literature and Postcolonial Studies. Edinburgh: Edinburgh University Press.

Cain, P.J. and A.G. Hopkins (2001). British Imperialism, 1688-2000. Harlow: Longman. Cannadine, David (2001). Ornamentalism. Oxford: Oxford University Press.

Carlisle, Janice (1996). "Introduction: Biographical and Historical Contexts," in: Charles Dickens, Great Expectations. Case Studies in Contemporary Criticism (ed. by Janice Carlisle). Boston: Bedford Books, pp. 3-21.

Connor, Steven (1985). Charles Dickens. Oxford: Basil Blackwell.

Dickens, Charles (1996). Great Expectations. Case Studies in Contemporary Criticism (ed. by Janice Carlisle). Boston: Bedford Books.

Grossman, Jonathan H (2015). "Living the Global Transport Network in Great Expectations." Victorian Studies 57:2, pp. 225-250.

Hewitt, Virginia (1998). "Beware of Imitations: the Campaign for a New Bank of England Note, 1797-1821." The Numismatic Chronicle 158, pp. 197-222.

House, Humphry (1950). The Dickens World. London: Oxford University Press.

Karskens, Grace (2013). "The early colonial presence, 1788-1822," in: The Cambridge History of Australia. Volume 1. Indigenous and Colonial Australia (Bashford, Alison and Stuart Macintyre, editors). New York: Cambridge University Press, pp. 91-120. 
Leavis, Q.D. (1970). "How we must read Great Expectations," in: Leavis, F.R and Q.D. Leavis. Dickens the Novelist. London: Chatto \& Windus, pp. 277-331.

Macintyre, Stuart (2009). A Concise History of Australia. Cambridge: Cambridge University Press.

Meckier, Jerome (1992). "Dating The Action In "Great Expectations": A New Chronology." Dickens Studies Annual 21, pp. 157-194.

Meckier, Jerome (2001). "'Great Expectations' and 'Self-Help'”: Dickens Frowns on Smiles." The Journal of English and Germanic Philology 100:4, pp. 537-554

Pecora, Vincent P. (2008). "Inheritances, Gifts, and Expectations." Law and Literature 20:2, pp. 177-196.

Poovey, Mary (2008). Genres of the Credit Economy. Mediating Value in Eighteenthand Nineteenth-Century England. Chicago: The University of Chicago Press.

Young, Arlene (1996). "Virtue Domesticated: Dickens and the Lower Middle Class." Victorian Studies 39:4, pp. 483-511.

\section{Cirkulacija kapitala u Velikim očekivanjima}

Članak razmatra temu stjecanja bogatstva i raspolaganja bogatstvom u romanu Velika očekivanja Charlesa Dickensa. Analiza je utemeljena na gledištu da roman nije primarno usredotočen na prikazivanje procesa proizvodnje bogatstva, već na cirkulaciju društvenog i ekonomskog kapitala. Protagonist romana slijedi određenu predodžbu o društvenoj mobilnosti (svoja velika očekivanja), koju naposljetku odbacuje te usvaja uobičajeno poimanje srednje klase o središnjoj važnosti napornog rada za stjecanje bogatstva. Međutim, razmatranjem narativnog oblikovanja odnosa protagonista i bogatstva, te narativnog oblikovanja cirkulacije bogatstva, članak nastoji pokazati da roman preispituje svoju deklariranu ideologiju stavljanjem naglaska na različite oblike transferiranja novca koji omogućuju likovima stjecanje društvenog i ekonomskog kapitala.

Ključne riječi: Charles Dickens, srednja klasa, kapital, rad, Britansko Carstvo 
